\title{
TWEE KATEGISMUSSE UIT DIE 16de EEU: 'N SPIEëL VAN AKSENTVERSKUIWING
}

\author{
l.. F. Schulze \\ Departement Dogmatologie \\ Potchefstroomse Universiteit vir $\mathrm{CHO}$ \\ POTCIIEFSTROOM
}

\begin{abstract}
Althongh I7h-century Calvinism intended to be faithful to Calvin its theology reveals some significant changes from the thought of the Genevan reformer. These differences manifest themsclves not only in dognnatic and ethical expositions, but also in catechisms. To illustrate this, the catechisms of Calvin and Perkins are compared with regard to certain aspects - in panicular as regards the doctrine of God the Creator. It is angued that even latc J6th-centun theology had stancd to change the course of development towards its modem direction in which the imponance of the human factor has gradualhy increased with the result that theology eventually can be secn as part of anthropology. In conclusion a few reasons for this development are suggested.
\end{abstract}

\section{INLEIDEND}

Die gereformeerde teologie van die 17de eeu wou die erfenis van die Reformasie en veral die denke van Calvyn bewaar en verdedig teen die Roomse aanslag van die Kontra-Reformasie aan die een kant en anabaptistiese en filosofiese opvattings - veral die filosofie van Descartes - aan die ander kant (kyk oor Descartes se filosofie Bohatec, 1966:1,22 e.v., 33 e.v.). Die geskiedenis toon egter dat hierdie goeie bedoelings van die Ortodoksie nie ten volle bereik is nie maar dat daar in die proses van bewaring en verdediging aksente gelê is wat soms drasties afgewyk het van die Reformasie. Dit beteken nie dat die Reformasie self teologies in alle opsigte eensternmig was nie. Daar was verskille tussen die Hervormers, byvoorbeeld in hulle Nagmaalsopvatting, in hulle visie op die verhouding van kerk en owerhede, in die vraag na die toelaatbaarheid van rente. Calvyn het egter hierdie verskille as minder belangrik gesien - sake wat nie die wese van die geloof geraak het nie - ook al sou hy later, na die aanval van Westphal, in die laaste uitgawe van die Institusie sy eie posisie ten aansien van die Nagmaal teenoor die Lutherane se opvatting duidelike afgrens (Itrst. 4.17.16 e.v.). Daarom kon hy teenoor Pighius, wat juis die verskille tussen die llervormers wou probeer uitwys, dit onomwonde in sy Defensio (1543) stel dat die 1 lervormers in die leer van die evangelie eenstemmig is (Calvyn, 1611:311; OC 6:250) en homself volkome met Luther vereenselwig: "die leer van Luther, wat ook ons s'n is" 
(la doctrine de Luther, qui est aussi la nostre - Calvyn, 1611:323).

Calvyn erken die natuurlike variasie in styl en uitdrukking van die Hervormers maar is oortuig dat hierdie natuurlike verskille in formulering geen leerverskille inhou nie en dat alle Hervormers, elk op sy karakteristieke wyse, dieselfde evangeliese waarheid verkondig (Calvyn, 1611:312; Schulze, 1971:32-33). Gevolglik vertoon die Reformasie in die rykdom van skakerings en formulerings 'n onmiskenbare "homogeniteit" van die leer.

Die vraag is nou of dit ook nog geld vir die teologiese ontwikkeling in die laat 16de en die $17 \mathrm{de}$ eeu. In die beantwoording van hierdie vraag loop die menings uiteen. So is daar byvoorbeeld net op die beperkte gebied van die vraag na Calvyn se invloed op Perkins en die teologiese ontwikkeling in Engeland die verskillende interpretasies van Breward (Inleiding, Perkins, 1970:14 e.v.), Chalker (1961, passim) en Shaw (1981, veral 3-75) en die verskillende menings van ander skrywers wat deur hulle bespreek word.

In plaas van die verskillende interpretasies te weeg, word hier getrag om langs 'n eenvoudiger en meer toegespitste weg 'n balans tussen die Reformasie en die eeu daarna op te stel. Dit word naamlik gedoen aan die hand van 'n vergelyking van Calvyn se Geneefse Kategismus met die kategismus van William Perkins. 'n Grondige vergelyking van die twee werke sal omvangryker wees as wat hier toelaatbaar is. Daarom word daar in die vergelyking veral op die oogmerke en die algemene inhoud van die kategismusse gelet met toespitsing op die uiteensetting van God die Skepper. Enkele ander aspekte sal net terloops vermeld word. Ten slotte word enkele redes as moontlike verklaring vir die verskille in die twee kategismusse aangevoer.

\subsection{Calvyn en Perkins}

Om die algemene dogmatiese ontwikkeling vanaf die Reformasie na die 17de eeu aan te toon is die keuse van Calvyn (1509-1564) as die een pool van vergelyking voor die hand liggend. Hy was immers dié samevatter van die insigte en leer van die Reformasie. Bowendien is hy die vader van die gereformeerde tradisie - 'n tradisie waarop uiteraard hier gekonsentreer word.

As tweede pool van vergelyking word William Perkins (1558-1602) geneem - nie omdat hy vandag nog 'n invloedryke teoloog sou wees nie, maar omdat hy aan die einde van die 16de eeu en deur die 17de eeu 'n groot invloed gehad het, nie net in Engeland nie maar veral deur sy leerling, William Ames (1576-1633), ook in die Nederlande (Reuter, 1940:11 e.v.) In die voorwoord van sy geselekteerde uitgawe van Perkins se werke teken Breward sy invloed só: 
William Perkins of Cambridge was the most widely known theologian of the Elizabethan church. By the end of the sixtecnth century he had replaced Calvin and Beza near the top of the English religious best-seller list. Even more important, his works were widely published outside Britain. Jewel, Foxe and Cartwright had bcen published overseas, but editions of their works never reached double figures. Al least fifty cditions of Perkins' works were printed in Switzerland, the same number in various parts of Germany, almost nincty in the Netherlands, with smaller prinlings in France, Bohemia, Ireland, Hungary, plus Iranslations into Spanish and Welsh published in London (in Perkins, 1970:xi).

\subsection{Die kategismus as samevatting van die leer}

Die kategismus wil altyd 'n kort samevatting van die Christelike leer wees. Bowendien verraai die inhoud van die kategismus watter elemente van die leer deur die betrokke outeur daarvan essensieel vir die kennis van die saligheid gesien word (vgl. Breward, in Perkins, 1970:140). Verder kan die inleiding, die inkleding en vormgewing van die kategismus lig werp op die outeur se leeropvatting en op sy siening van die funksie van die leer in die kerklike lewe. In hierdie lig word die kategismus van Calvyn en dié van Perkins dan met mekaar vergelyk.

Dit gaan dus hier nie om die invloed van die kategismus self as leerboek in die kerklike lewe nie maar om die kategismus as spieël van die leeropvatting en -ontwikkeling gedurende die ontstaanstyd daarvan.

\subsection{Die ontstaan van die twee kategismusse}

Die twee kategismusse wat hier vergelyk word, is albei produkte van die lode eeu, en hulle ontstaantyd lê byna 'n halfeeu uit mekaar.

Calvyn se Geneefse Kategismus het in $\mathbf{1 5 4 2}$ ontstaan en sy poging van vyf jaar tevore vervang. Hierdie eerste kategismus (1537) was immers nog nie in vraag-enantwoordvorm opgestel nie maar het bestaan uit samevattende stellings uit sy Institusie van 1536 (Simpson, Voorwoord, in Calvyn, 1981). Dit was dus nog nie 'n kategetiese leerboek in die ware sin van die woord nie. By sy terugkeer van Straatsburg na Genève wou hy ten alle koste hè dat sy kerkorde - die Ordonnances ecclesiastiques - en 'n 
kategismus deur die Raad goedgekeur word sodat daar orde in die kerklike lewe van Genève kon kom. So word die kategismus haastig geskryf - nou in die vorm van vraag en antwoord - en verskyn onder die titel Kategismus van die kerk van Genève1.

Kort voor sy dood, wanneer hy van die ander predikante van Genève afskeid neem, herinner hy hom die terugkeer na Genève en die ontstaan van die kategismus:

On my return from Strasbourg, I composed the Catechism - and in haste; for I would never accept the ministry until they had taken an oath on these two points, that is, to preserve the Catechism and discipline. And while I was writing it they came to fetch pieces of paper the size of my hand and carry them to the printer's. Though Monsieur Pierre Viret was then in this lown, do you think I ever showed him a word of it? I newer had the time. I have sometimes indeed thought of putting some finishing touches to it if I had had the leisure" (Parker, 1975:155; vgl. OC 9:894).

Die kategismus is spoedig uit Latyn in verskillende tale vertaal. "Die vertalings wat ons die meeste verbaas, is dié in Grieks en Hebreeus" (Simpson, in Calvyn, 1981, Voorwoord).

Perkins het sy kategismus in 1590 geskryf. Uit die aantal uitgawes wat dit gehad het, (tot so laat as 1905 in Nederland) is die populariteit van hierdie kategismus duidelik af te lees. Dit het byvoorbeeld in Engeland alleen tussen 1590 en 1677 nie minder as 21 keer verskyn nie (Breward, in Perkins 1970:620-621). Die titel van die kategismus is The foundation of Christian religion gathered into six principles. Breward het die volledige teks van die kategismus in sy versameling opgeneem (in Perkins, 1970:146167), en dit word hier as bron gebruik.

\section{ENKELE PUNTE VAN VERGEL,YKING}

By hierdie vergelyking word slegs ingegaan op die oogmerke, die inhoud en die Godsleer soos verwoord in die kategismus van Calvyn en Perkins onderskeidelik. Na elke vergelyking van elk van hierdie drie aspekte sal 'n samevatting gegee word.

${ }^{1}$ Catéchisme de l'église de Genève. Lat. 1545: Catechismus ecclesiae Genevensis. Bcide dic Franse en Latynse teks verskyn in OC 6:1-160. Hier word deurgaans gebruik gemaak van H.W. Simpson se vertaling, gebaseer op die Latynse teks wat deur Beza versorg en in 1575 in Genève by Santandreanus verskyn het. (Vir ander uitgawes en vertalings van die kategismus kyk die Catalogus operum Calvini chronologicus in $\mathrm{OC}$ se indeks, pp. 463 e.v.) 


\subsection{Die oogmerke van die kategismus by Calvyn}

\subsubsection{Verbondsonderrig}

Uit die aanhaling van Calvyn hierbo is dit duidelik dat hy nie alleen die kerklike orde in Genève deur middel van sy Ordonnances ecclesiastiques met goedkeuring van die Raad gereèl wou kry nie maar ook die onderrig van die kerklike jeug volgens 'n vaste patroon wou orden. Daarom moes die Raad sy kategismus goedkeur. Wanneer hy die hervatting van sy bediening in Genève van hierdie twee sake afhanklik maak, word die hoë prioriteit wat hy aan die kerklike orde en die verbondsonderrig toeken, baie duidelik. Hoe hoog hy die verbondsonderrig van kinders geag het, blyk verder uit sy briefwisseling en uit 'n bepaling in sy Ordonnances "dat ouers hulle kinders elke Sondagmiddag by die kerk moes besorg met die oog op kategetiese onderrig. Ouers wat hiermee in gebreke gebly het, moes voor die raad van Genève verantwoording doen" (Simpson, Voorwoord, in Calvyn, 1981).

Hoewel Calvyn nòg in sy begeleidende brief aan die kerke van Oos-Friesland nòg in sy voorwoord aan die leser die term verbondsonderig gebruik, is dit vir hom tog die saak waarom dit gaan. Dit blyk eerstens daaruit dat die kategismus bedoel is vir die onderrig van die kerklike jeug. Reeds uit die titel van die kategismus word dit duidelik: Die kategismus van die kerk in Genève. Dit is ' $n$ formulier om kinders te onderrig in die leer van Christus (1545) (1981:1). In sy woord aan die leser kom Calvyn (1981:5) hierop terug:

In die Kerk is daar altyd daarop ag geslaan en daar is ook noulettend daarvoor gesorg dat kinders behoorlik in die Christelike leer onderwys word. Om dit met groter gerief te laat geskied is skole geopen en aan elkeen is opgedra om sy eie gesin na behore te onderrig, maar volgens openbare gewoonte en instelling is ook anvaar dat kinders in ons kerke ondervra moes word oor enkele hoofstukke wat onder alle Christene algemeen bekend behoort te wees.

Om hierdie kerklike ondervraging ordelik te laat geskied, "is 'n formulier voorgeskryf wat as 'n Kategismus of onderwysing bekend gestaan het" (Calvyn, 1981:5). Sedert die duiwel die kerk van God vermink het, sê Calvyn, is hierdie "heilige instelling" vernietig en die fondament van die kerk ondergrawe. Sy kategismus wil maar net herstel wat ondertussen verlore geraak het.

Die werk wat ons nou bekendstel, is niks anders as die gebruik van dit wat eenmaal deur Christenc en opregle aanbidders van God waargeneem is nie. Dit het nooit verlore gegaan nie, behalwe wannecr die kerk volkome bedorwe was (Calvyn, 1981:5). 
Dat dit vir Calvyn om kerklike onderrig gaan, is uit bostaande sonder meer duidelik.

Maar dat dit om verbondsonderrig gaan, is tweedens duidelik uit die feit dat Calvyn hierdie onderwysing van die jeug aan die doop verbind. Twee aanhalings uit sy brief aan die kerke van Oos-Friesland stel dit baie duidelik:

Met hicrdic doel voor oé (d.i. geloofseenheid - L.F.S.) behoort 'n plegtige geloofsbelydenis wat ten nouste aan die algemene doop verbonde is, van die grootste bulang te wees. Daarom behoort daar nic alleen 'n voorlgeselte censgesindheid vor die geloofslecr onder ons te bestaan nie, maar is cok 'n eenvormige kategismusformulier vir al ons kerke gewens.

Effens verder vra Calvyn: "Want watter nut het die doop nog as dit nie daarin gevestig is dat ons almal saam tot een geloof instem nie?"

Die draagwydte van hierdie retoriese vraag word duidelik wanneer Calvyn in sy kommentaar op Efesiërs 4:5 die volgende skryf:

The frequent repetition of the word one is emphalic. Christ cannot be divided. Faith cannot be rent. There are not various baptisms, but one which is common to all. God cannot cease to be one, and unchangeable ... Fath, and baptism, and God the Father, and Christ, ought to unite us, so as almost to become one man ... The unity of foith which is here mentioned, depends on the one, ctcrnal truth of (jod, on which it is founded (Calvyn, 1979:269).

\subsubsection{Geloofseenheid}

'n Tweede oogmerk van die kategismus het uit die vorige paar aanhalings reeds duidelik geword, naamlik om die eenheid van die geloof te bevorder. Hoewel Calvyn "'n eenvormige kategismusformulier vir al ons kerke" gewens ag - sy eie kategismus(!) is hy daarvan bewus dat die ideaal nie haalbaar is nie. ' $n$ Verskeidenheid kategismusse met verskillende onderrigmetodes is toelaatbaar mits hulle "ons almal op Christus alleen" rig (Calvyn, 1981:1). Tog hoop Calvyn dat sy geskrifte, en veral sy kategismus, kerke aan mekaar sal verbind. Hy skryf aan die kerke in Oos-Friesland (1981:2): "Weliswaar sal ander soorte geskrifte aandui wat ons gevoel in die godsdiens was; maar die eensgesindheid in leer wat die kerke onderling het, kan nie met 'n duideliker bewys waargeneem word as in die Kategismus nie. 


\subsection{Die oogmerke van die kategismus by Perkins}

\subsubsection{Die bestryding van onkunde}

Dit is nie net die Europese vasteland wat veral in die vroeë $16 \mathrm{de}$ eeu 'n ryk oes aan kategismusse opgelewer het nie. Ook in Engeland het daar tussen 1558 en 1660 'n groot aantal kategismusse die lig gesien. Baie hiervan het uit Puriteinse geledere ontstian en was bedoel om die kort kategismus in The Book of Common Praner aan te vul of selfs te vervang. Onder al hierdie kategismusse was dié van Perkins een van die invloedrykste. 'n Mens kan dit maklik begryp as die vele herdrukke daarvan in gedagte gehou word. Bowendien is Perkins self deur J.I. Packer getipeer as "the C.S. Lewis of the Puritan Movement" (aangehaal deur Shaw, 1981:5).

Hierdie invloedryke teoloog noem sy kategismus The foundation of Christian religion gathered into six principles en rig dit "to all ignorant people that desire to be instructed" (Perkins, 1970:142).

In die inleiding wend Perkins hom tot hierdie arme mense wat in onkunde lewe. Hulle onkunde toon hy aan met behulp van 32 stellings wat as algemene opvattings deur die onkundiges gehuldig word. Ilier volg enkele van die verkeerde opvattings:

2. That God is served by the rehearsing of the Ten Commandments, the Lord's Prayer and the Creed.

3. That ye have believed in Christ ever since you could remember.

5. That none can tell whether he shall be saved or no certainly, but that all men must be of a good belief.

9. That a preacher is a good man no longer than he is in the pulpit.

11. That it is an easier thing to please God than to please our neighbour.

13. That it is the safest to do in religion as most do.

19. That it was a good world when the old religion (die Rooms-Katolisisme L.F.S.) was, because all things were cheap.

22. That every man must be for himself and God for us all.

25. That a man prayeth when he saith the Ten Commandments.

26. That a man eats his maker in the Sacrament.

30. That a man may go to wizards, called wise men, for counsel, because God hath provided a salve for every sore.

31. That ye are to be excused in all your doings, because the best men are sinners (Perkins, 1970:142-144). 
In sterk taal kritiseer Perkins hierdie en soortgelyke opvattings:

These and such like sayings, what argue they but your gross ignorance? Now where ignorance reigneth, there reigns sin: and where sin reigns, there the devil rules: and where he rules, men are in a damnable case (Perkins, 1970:144)

Wanneer die onkundiges hierop sou antwoord dat hulle die Apostoliese Geloofsbelydenis, die Onse Vader en die Tien Gebooie kan opsê, antwoord Perkins dat dit nie genoeg is nie tensy hulle die betekenis van die woorde verstaan en die regte gebruik van hierdie dinge kan maak, "by applying them inwardly to your hearts and consciences and outwardly to your lives and conversations" (Perkins, 1970:144). Juis hierin faal die onkundiges.

Die doel van die kategismus van Perkins is juis om die sonde te bestry deur die onkunde weg te neem en die mense tot kennis, geloof en berou te bring. Hy wys meteen op die struktuur van die kategismus, die metode waarop dit geleer moet word en die vrug wat daaruit sal volg:

And for an help in this your ignorance, to briag you to true knowledge, unfeigned faith and sound repentance, here I have set down the principal points of the Christian religion in six plain and easy rules, even such as the simplest may easily learn: and here-unto is adjoined an exposition of them word by word. If ye do want other good directions, then use this my labour for your instruction. In reading of it, first learn the six principles: and when you have them without book and the meaning of them with withal, then learn the exposition also: which being well conceived and in some measure felt in the heart, ye shall be able to profit by sermons (whereas now ye cannol) and the ordinary parts of the Catechism, namely the Ten (ommandments, the Creed, the Lord's Prayer and the institution of the two sacraments, shall the more easily understood (Perkins, 1970:144-145).

\subsubsection{Kennis en die gewete}

Uit bostaande is dit duidelik dat Perkins oortuig was dat kennis van die wet, die geloofsbelydenis en die gebed van die Here nie genoeg was nie. Breward som dit goed op: "Rather it was fundamental to begin with man's situation in order to bring him to the point where he could pray and confess because he had true faith" (in Perkins, 1970:140).

Kennis van hierdie dinge is nog nie ware kennis nie. Trouens, die kennis moet eers met insig gepaard gaan en tot die regte toepassing ("application") lei, voordat dit ware en sinvolle kennis kan wees. So word die kennis dan eintlik voorwaarde vir die funksionering van die gewete. Immers, Satan se ryk is gebou op onkunde, dwaling, 
onheiligheid en ongehoorsaamheid, en ten einde hierdie toestand te besef "the understanding must first of all conceive, or at least have means of conceiving, before conscience can constrain; because it bindeth by virtue of known conclusions in the mind" (Workes, 1:363, 522; aangehaal deur Breward, in Perkins, 1970:139-140).

\subsubsection{Die kategismus as korreksie en aanvulling van ander}

Perkins het ook 'n psigologies-pastorale motief vir sy kategismus. Die mense moet naamlik weet dat daar grade van geloof is. Indien dit nie verduidelik word nie, ontstaan daar ernstige pastorale gevolge, naamlik dat mense wat nog nie 'n sterk geloof het nie, hulle nie meer as kinders van God sal beskou nie en wanhopig kan raak. Indien mense sou meen dat geloof slegs 'n ten volle versekerde geloof is, sou baie wat waarlik die Naam van Christus dra, uit die rol van die kinders van God uitgeskakel word. Hieroor laat Perkins hom verder soos volg uit:

\footnotetext{
This point of doctrine serves to rectify and in part to expound sundry catcchisms, in that they secm to propound faith unto men of so high a reach as few can altain unto it: defining it to be a certain and full persuasion of (iod's love and favour in Christ (Workes 1:606; aangehaal deur Breward, in Perkins, 1970:140).
}

In die uiteensetting van sy kategismus kom hierdie saak dan ook breedvoerig aan die orde, soos blyk uit die volgende vrae waarop antwoorde gegee word: "Are there diverse degrees and measures of faith? What is the least measure of true faith that a man can have? How do you know that such a man hath faith? What is the greatest measure of faith? When shall a Christian heart come to this ful assurance?" (1970:158).

Samevatting ten opsigte van die oogmerke

* Calvyn se kategismus is bedoel vir die onderrig van die jeug. Daarteenoor is Perkins se kategismus bedoel vir volwassenes. Hulle moet deur selfstudie 'n funksie analoog aan dié van die kategismusprediking vervul.

- Die kategismus van Calvyn is as kerklike leerboek bedoel, terwyl die kategismus van Perkins in 'n meer algemene godsdienstige behoefte moes voorsien. Nêrens in die voorwoord blyk dit dat Perkins se kategismus vir kerklike gebruik gekonsipieer en bestem was nie.

- Hoewel Calvyn nòg in sy brief aan die kerke van Oos-Friesland, nòg in sy voorwoord aan die leser nòg in sy behandeling van die sakramente (vgl. GK, vr. 
311 e.v., 1981:56 e.v.) die verbond by name noem, is sy kategismus duidelik vir die verbondsjeug bedoel. Die verbinding van die kategetiese onderrig met die doop asook die uitgesproke kerklike karakter van sy kategismus getuig daarvan. Daarenteen figureer die verbond in Perkins se verduideliking sterk (vgl. 1970:162164). 2 Die genadeverbond word by Perkins baie sterk kondisioneel en kontraktueel geteken - wat nooit by Calvyn die geval was nie (vgl. Torrance, 1982:269, 272). Dit is egter jets wat "ignorant people" moet weet. Nêrens in die inleiding word hierdie kategismus egter aan die doop van die onkundiges verbind nie. Anders gesê: hoewel die verbond in die kategismus van Perkins figureer - iets wat reeds op die opkomende federale teologie wys - word die kategismus self nie eksplisiet binne die kerklike verbondskader geplaas nie.

- Vir Calvyn is kennis "eksistensieel". Kennis van dit wat die Skepper openbaar, raak die skepsel se hele bestaan. Vir Calvyn is kennis die saligmakende kennis van God en van Christus; om Hom te ken is die ewige lewe en lei tot "die eerbied en aanbidding wat aan Hom verskuldig is" (GK, vr. 300; vgl. Inst. 1.2.2). Kennis sonder godsvrug is geen kennis nie: "... ons sal nooit die bewering maak dat God geken word waar geen godsdiens of gedsvrug bestaan nie" (Inst. 1.2.1; Afr. vert. 1:117). Daarom is geloof vir Calvyn "'n eksplisiete kennis van die goedheid van God" (Inst. 3.2.2, - Afr. Vert. 3:711; vgl. ook 3.2.3, 7 en GK, vr. 112). Hoe 'n mens ook al Perkins se opvatting van kennis sou wil omskryf - 'n teoretiese abstraksie of ' $n$ bloot verstandelike wete - is dit tog duidelik dat kennis vir hom geen eksistensiële saak is nie. Wat Perkins dus kennis noem, is vir Calvyn geen kennis nie (vgl. Inst. 1.2.1). Daarom is dit vir Perkins nie genoeg dat die geloofsbelydenis, die wet en die gebed geken word nie maar moet die toe-eiening ("applying them inwardly") as aparte akte daar bykom. Daarom kan kennis ook blote substraat vir die funksionering van die gewete wees. In ooreenstemming hiermee word geloof nie in terme van kennis nie maar bloot in terme van "persuasion" gedefinieer (vgl. Perkins, 1970:155, 158).

- Moontlik is die duidelikste aanwysing van 'n teologiese klimaatsverandering die feit dat Perkins uit pastorale bewoënheid teenoor geloof as "a certain and full persuasion" die aksent gaan lê op die grade ("degrees") van die geloof "to rectify and in part to expound sundry catechisms" (Perkins, 1970:140). Hierdie kritiek tref kwalik Calvyn se kategismus, waar geloof omskryf word as "'n vaste en onwrikbare kennis van die vaderlike goedheid van God jeens ons" (GK, vr. 112).

${ }^{2}$ Die vrae van hierdie kategismus is nie genommer nie en bemocilik noukeurige verwysings. 
Maar as ons die - meer in ooreenstemming met die Melanchthon geformuleerde "gewisse kennis" buite rekening laat en net die "vaste vertroue" betrag, tref Perkins se kritiek gewis tot 'n mate die Heidelbergse Kategismus (S. 7, vr. 21). Natuurlik ken Calvyn ook die aanvegtinge, die geringheid, die groei van die geloof (vgl. byvoorbeeld Inst. 3.2, 19-22), maar dis 'n ander saak as die vraag na die aard van die geloof. In die veranderde teologiese klimaat het Perkins se pastorale bewoënheid hom verhinder om die onderskeid tussen die twee vraagstellings te sien en het hy die vraag na die aard van die geloof gaan interpreteer as die vraag na die mate van geloof wat 'n mens behoort te hê.

\subsection{Die inhoud van die kategismus by Calvyn}

Die Geneefse Kategismus begin met 'n uiteensetting van die geloof, dit wil sè 'n verklaring van die Apostoliese Geloofsbelydenis (vr. 1-131) en gaan byna naatloos oor in 'n verklaring van die Tien Gebooie (vr. 132-233). Dan volg 'n verduideliking van die gehed, toegespits op die Onse Vader (vr. 234-296). Ten siotte, as "die vierde deel van ons diens aan God" (vr. 297, Calvyn, 1981:54), word gehandel oor die Woord van God, in besonder oor die prediking van die Woord en die sakramente wat God aan sy Woord verbind het (vr. 297-374).

Dit is interessant om te sien hoe hierdie vier aspekte van ons kennis en diens van God in die inleidingsvrae van die Gieneefse Kategismus saamgebundel is.

Die eerste vraag en antwoord is van fundamentele belang:

I Leraar (=L): Wat is die belangrikste doel van die mens se lewe?

Seun (=S): $\quad$ Om God deur wie die mens geskape is te leer ken (Calvyn, 1981:5).

In vraag 6 word nader op die antwoord van vraag 1 ingegaan: dis 'n kennis wat bring tot die regte verering van God. Wanneer in vraag 7 dan na die regte verering gevra word, kom die vier hoofdele van die kategismus in die antwoord in sig. By die aanhaling van die antwoord op vraag 7 sal die vier hoofdele tussen hakies aangetoon word. Luister na Calvyn: 
6 L: Wat is verder ware en egte kennis van God?

S: Dit is wanneer Hy so geken word dat die eer wat aan Hom verskuldig is, aan Hom betoon word.

7 L: Wat is die wyse waarop Hy na behore vereer moet word?

S: Dit is as ons vertroue ten volle in Hom gevestig is (die geloof - L.F.S.); as ons ons beywer om Hom met ons hele lewe te dien deur aan sy wil gehoorsaam te wees (die wet - L.F.S.); as ons Hom aanroep so dikwels as wat nood ons druk; as ons ons saligheid en alle goed wat nagejaag kan word, in Hom soek (die gebed - L.F.S.); as ons Hom ten slotte in hart en mond as die Skepper van alle goeie dinge erken (Woord en Sakramente L.F.S.) (Calvyn, 1981:6).

In die woorde van Simpson se vertaling (Calvyn, 1981:6) begin vraag 8 "om dit nou een vir een te bespreek en breedvoeriger te verduidelik." Die eerste aspek, naamlik om God ten volle te vertrou, loop uit op vraag 14: "Die basis en grondslag daarvan om ons vertroue in God te stel, is dus om Hom in Christus te ken" (1981:7) terwyl vraag 15 na die "kern van hierdie kennis" vra en die antwoord sê dat dit "saamgevat (word) in die geloofsbelydenis" (1981:7). Die tweede deel van antwoord 7, naamlik om God met ons hele lewe in gehoorsaamheid te dien, weerklink in vrae 129-132 (1981:26) en lei na die uiteensetting van die wet. Die twee fasette van die derde deel van antwoord 7 kom ter sprake, allereers by die begin van die deel wat oor die gebed handel (vr. 234; 1981:41) en weer 'n bietjie later in vraag en antwoord 251 (1981:44-45), terwyl "die vierde deel van ons diens aan God" in vraag 297 aan die orde kom (1981:54).

Dit is duidelik dat al vier hierdie elemente vir Calvyn onontbeerlik is om God reg te ken en gevolglik welbehaaglik te dien. Sy integrasie van die verskillende fasette tot elemente van die regte verering en diens van God is indrukwekkend. Sy keuse van die inhoudelike aspekte is egter nie oorspronklik nie. Dit kom grootliks uit die Middeleeuse tradisie en die res was tipies van die Reformasie.

Dit was immers reeds gedurende die Middeleeue die taak van die priesters om die "hoofsake" (summa) van die Christelike leer vir die kerkvolk te verklaar en hulle dit in te prent. Hierdie "hoofsomme" van die leer, wat elke gelowige vir sy saligheid moes ken, was die dekaloog, die Apostolicum en die Onse Vader. Die Reformasie het by hierdie tradisie aangesluit maar het die wetsprediking van die biegpraktyk ontkoppel en in die plek van laasgenoemde die aksent op die kategetiese onderrig van die jeug 
gelê. So het die "hoofsomme" van die Christelike leer die ruggraat van die kerklike onderrig en in besonder van die jeugonderrig gevorm.

Hierdie toedrag van sake word reeds in Luther se ontwikkelingsgang as hervormer duidelik. So vroeg as 1516-1517 het hy 'n reeks preke oor die Tien Gebooie en die Onse Vader gehou. Daarin het hy reeds gewys op die gebrek aan onderwys van die jeug. In 1520 verskyn sy Kurze Form van die drie hoofsomme van die leer, waarvan die kennis noodsaaklik was vir elkeen se saligheid (Schulze, s.j.:9). Nege jaar later verskyn sy Groot Kategismus en sy Klein Kategismus. Laasgenoemde is nog steeds 'n verduideliking van die wet, die Apostolicum en die gebed van die Here, gevolg deur' $n$ verduideliking van die sakramente, omdat dit een van die sake was wat in die Reformasie in die brandpunt van die stryd was.

Die behandeling soms van één maar gewoonlik van al drie die hoofsomme, dikwels met die sakramente daarby, vorm die globale inhoud van die ryk verskeidenheid kategetiese werke wat gedurende die Reformasie ontstaan het. So byvoorbeeld het Oecolampadius se Frag und Antwort, wat in 1526 in Basel verskyn het - nog voor Luther se Klein Kategismus - al drie hoofsomme én die doop en Nagmaal behandel. terwyl Capito se Der Kinderbericht (1527) hoofsaaklik 'n verklaring van die Twaalf Artikels was.

Dit is in hierdie tradisie, wat deels uit die Middeleeue stam en origens (wat die insluiting van die sakramente betref) gangbare praktyk van die Reformasie was, waarbinne die Geneefse Kategismus ook val. 'n Mens sou hieruit kan aflei dat beide Rome en die Reformasie eenstemmig was in die opsig dat kennis van die "hoofsomme" vir elke gelowige noodsaakik was.

\subsection{Die inhoud van die kategismus by Perkins}

Teen hierdie agtergrond staan Perkins se kategismus eers behoorlik afgeëts. Waarom hy van hierdie tradisie afwyk, kan seker stof tot spekulasie bied. Die feit bly staan dat hy met sy "ses beginsels" ' $n$ ander pad inslaan. Ook Breward wys hierop as hy skryf: "Unlike earlier catechisms, he did not build his questions around the framework of the Apostles' Creed, Lord's Prayer and Decalogue" (inleiding, Perkins, 1970:140).

Wanneer ons in ag neem dat die inhoud van die kategismus dit wat die outeur van wesensbelang ag, reflekteer, is dit duidelik dat hier 'n reduksie van die noodsaaklike 
leer plaasvind.

Hier volg Perkins se ses beginsels wat volgens hom funderend is vir die Christelike godsdiens. Elke beginsel word gevolg deur'n aantal Skrifbewyse. Die vierde beginsel word hier volledig met Skrifbewyse aangehaal, omdat dit 'n mooi voorbeeld van Perkins se soort "atomistiese" bewysvoering lewer.

The first principle

Q What dost thou believe concerning God?

A There is one God, creator and governer of all things, distinguished into the Father, the Son and the Holy Ghost.

The second principle

Q What dost thou believe concerning man and concerning thine own self?

A All men are wholly corrupted with sin through Adam's fall and so are become slaves of Satan and guilty of eternal damnation.

The third principle

Q What means are there for thee to escape this damnable estate?

A Jesus Christ, the eternal Son of God, being made man, by his death upon the cross and by his obedience hath perfectly alone by himself accomplished all things that are needful for the salvation of mankind.

The fourh principle

Q But how mayest thou be made partaker of Christ and his benefits?

A A man of contrite and humble spirit, by faith alone apprehending and applying Christ with all his merits unto himself, is justified before God and sanctified.

1. A man of contrite and humble spirit. Isa. 57.15; Psa. 51.17 
2. By faith alone. Mark. 5.36; Num. 21.19; John 3.14-15.

3. Apprehending and applying Christ with all his merits unto himself. John 1.12; 6.35 .

4. Is justified before God. Rom. 4.3, 6-7.

5. And sanctified. Acts $15.19 ; 1$ Cor. 1.30 .

\section{The fifth principle}

Q What are the ordinary or usual means for obtaining of faith?

A. Faith cometh only by the preaching of the Word and increaseth daily by it: as also by the administration of the sacraments and prayer.

The sixth principle

Q What is the estate of all men after death?

A. All men shall rise again with their own bodies to the last judgment which being ended, the godly shall possess the kingdom of heaven: but the unbelievers and reprobates shall be in hell, tormented with the devil and his angels for ever (Perkins, 1970:146-148).

Samevatting ten opsigte van die inhoud

* Hoewel Perkins ook An Exposition of the Lord's Praver (1592) en An Exposition of the Symbole (1595) die lig laat sien het, het hy dit tog nie nodig geag om hierdie twee van die "hoofsomme" van die leer in sy kategismus op te neem nie. Sy kategismus wil 'n preliminêre soort "kortbegrip" wees wat die essensiële van die Christelike geloof saamvat. Dit moet die onkundiges help om preke beter te verstaan en die hoofsomme, "the ordinary parts of the Catechism", (Perkins, 1970:145), makliker te verstaan. Daarmee is die hoofsomme saam met die prediking in ' $n$ aanvullende rol geplaas. Hier wyk Perkins inderdaad af van die gebruik van die Reformasie. 
- Wanneer die hoofsomme as leerstof verdwyn, kry die kategismus ook ' $n$ ander inhoud. Seker, die inhoud is Bybels verantwoord en goed "Calvinisties". Tog is dit opvallend dat wat weergegee word, veral op die mens en sy saligheid betrekking het. Die eerste beginsel van Perkins se kategismus handel immers oor God en die ander vyf oor die mens en sy toestand. Hierdie gegewens korreleer met wat in die vorige samevatting ten opsigte van Perkins se "pastorale" bewoënheid en die inhoud en funksie van kennis opgemerk is.

\subsection{Die Godsleer by Calvyn}

Hier volg slegs enkele aspekte van die Eerste Artikel soos dit by Calvyn en Perkins se kategismusse na vore kom.

Die Godsleer van Calvyn word binne die kader van die Apostolicum behandel. Dit gebeur ook later by die Heidelberger. Trouens, daar is inhoudelik groot ooreenkoms tussen die Geneefse en die Heidelbergse Kategismus (vgl. Wendel, 1963:80).

Nadat die leerling die Twaalf Artikels as kern van die kennis van God in Christus opgesê het, volg die vraag na die verdeling van die Twaalf Artikels (GK, vr. 17 en 18). Onmiddellik hierna kom, net soos in die Heidelberger, die Triniteit ter sprake. Daarna moet die leerling die Eerste Artikel opsê, en dan kom die vraag:

22. L: Waarom noem jy Hom Vader?

S: Met my oë in die eerste plek gerig op Christus wat sy Wysheid is en voor alle tye deur Hom voortgebring en na hierdie wèreld gestuur en as sy Seun geopenbaar is. 'Tog lei ons hieruit af dat Hy ook ons Vader is aangesien God Jesus Christus se Vader is" (Calvyn, 1981:8).

Daarna volg ' $n$ vraag oor die benaming Almagrige en word geantwoord dat ons nie aan 'n abstrakte, werklose almag moet dink nie, maar dat dit gaan om die werksame almag van God, wat "alles in sy mag en in sy hande het" (vr. 23; 1981:8). Op die vraag waarom Hy "Skepper van hemel en aarde" genoem word, volg die antwoord dat Hy Hom deur sy werke aan ons geopenbaar het en ook daarin deur ons gesoek moet word (vr. 25). Nadat die betekenis van "hemel en aarde" uiteengesit is (vr. 26), volg drie vrae oor die voorsienigheid: eerstens oor die voorsienigheid self (vr. 27), tweedens oor die voorsienigheid en die goddelose mense en duiwels (vr. 28), en laastens oor die voordeel wat hierdie kennis vir ons inhou (vr. 29). 
Wie die eerste hoofstukke van Calvyn se Genesiskommentaar lees, vind daarin een groot lofsang op die grootheid en die vaderlike wysheid en goedheid van die Skepper. Dieselfde refrein word hier in die Geneefse Kategismus gevind. Ter illustrasie hiervan word net die laaste deel van die antwoord op vraag 27 hier aangehaal. Dit toon meteen die opvoedkundig minder geslaagde element in die kategismus - die lang en moeilike antwoorde wat soms gegee moet word.

Uit die feit dat Hy die Skepper van die hemel cn die aarde is, pas dit ons dus om af te lei dat Hy die enige God is wal deur sy wysheid, goederticrenheid en lydsaambeid dic hele orde en verloop van die natuur bestuur; dat Hy dic bewerker van reen en droogie, van hael en storms, maar ook van mooiweer is; dat Hy uit goedertierenheid die aarde vrugbaar maak en wanneer Hy sy hand daarvan onttrek dit weer onvrugbaar maak. Deur Hom ontstaan gesondheid en siekte; aan sy gesag is alles onderworpe en aan sy wil is alles gehoorsaam (Calvyn, 1981:9).

Die deugde van God wat hier as't ware in sy werke as "Skepper van hemel en aarde" ingeweef is, is sy almag, wysheid, goedertierenheid en lankmoedigheid.

\subsection{Die Godsleer by Perkins}

Die "eerste beginsel" van Perkins is reeds hierbo aangehaal. Daarin gaan dit om die geloof omtrent God, want die vraag is hier: "What dost thou believe concerning God?" In die tweede deel van sy kategismus word hierdie beginsel verklaar. Om toegang tot Perkins se gedagtegang te verkry, word die eerste vier vrae en antwoorde hier volledig aangehaal.

The first principle expounded

Q What is God?

A God is a spirit or spiritual substance, most wise, most holy, eternal, infinite. John 4.24.

Q How do you persuade yourself that there is a God?

A Besides the testimony of the scriptures, plain reason will show it.

Q What is one reason? 
A When I consider the wonderful frame of the world, methinks the silly creatures that be in it could never make it. Neither could it make itself and therefore besides all these, the maker of it must be God. Even as when a man comes into a strange country and sees fair and sumptuous buildings, and yet finds no living creatures there, he will not imagine that either birds or beasts reared those buildings, but he presently conceives that some men either were or have been there. Rom. 1.20; Acts 14.17.

Q What other reason have you?

A A man that commits any sin, as murder, fornication, adultery, blashemy, etc., albeit he doth so conceal the matter that no man living know of it, yet oftentimes he hath a griping in his conscience and feels the very flashing of hell-fire; which is a strong reason to show that there is a God before whose judgment seat he must answer for his fact. Rom. 2.15; Gen. 3.8, 19; 42.21. (Perkins, 1970:148-149).

Ná 'n vraag oor hoeveel gode daar bestaan, volg daar weer ' $n$ vraag en antwoord wat iets van die gedagtegang van Perkins laat błyk:

Q How do you conceive this God in your mind?

A Not by framing an image of him in my mind (as ignorant folks do, that think him to be an old man sitting in heaven) but I conceive him by his properties and works" (1970:149).

Hierop volg die bespreking van sy "chief properties" wat in die "eerste beginsel" genoem is, naamlik sy wysheid, heiligheid, ewigheid en oneindigheid. Sy heiligheid kom daarin tot openbaring dat Hy uiters regverdig en genadig ("most just and merciful") teenoor sy skepsels is. Onder God se oneindigheid word ook (taamlik formeel) sy almag ingesluit: "... he is infinite, both because he is present in all places and because he is of power sufficient to do whatsoever he will" (Perkins, 1970:150).

Op die vraag wat die werke van God is, kom die skepping en onderhouding ter sprake. Hierop volg een enkele vraag oor die voorsienigheid:

Q How know you that God governeth every particular thing in the world by his special providence? 
A To omit the scriptures, I see it by experience. Meat, drink and clothing, being void of heat and life, could not preserve the life of men unless there were a special providence of God to give virtue unto them. Matt. 10.30; Prov. 16.33; Lev. 26.26; Matt. 4.4" (Perkins, 1970:150).

\section{Samevatting ten opsigte van die Godsleer}

'n Vergelyking van die twee kategismusse se verduideliking van die Eerste Artikel van die Apostolicum toon dat hier méér op die spel is as blote verskille in individuele formulering. Dit kan geillustreer word deur kortliks die individuele verskille en ooreenkomste van Luther, Calvyn en die Heidelbergse Kategismus se verklaring van die eerste sin van die Twaalf Artikels te vergelyk.

L.uther begin die verklaring in sy Klein Kategismus met die bekende persoonlike geloofsbetrokke formulering: "Ich glaube, dass mich Gott geschaffen hat sammt allen Creaturen." Hierna word dadelik - nog in dieselfde sin (!) - oorgegaan na die voorsienigheid en word bely dat God my liggaam en siel, ledemate, verstand en sintuie gegee het en nog bewaar. Daarna word die daaglikse versorging met alles wat nodig is, bely en dat Hy my teen alle gevare en kwaad beskerm. Dan kom die vaderlike goedheid van God na vore: "... und das alles aus lauter väterlicher, göıtlicher Güte und Barmherzigkeit, ohne alle mein Verdienst und Würdigkeit; dess alles ich ihm zu danken und zu loben, und dafür zu dienen und gehorsam zu sein schuldig bin" (l.uther, 1919:78).

Daar moet in ag geneem word dat Luther 'n klein kategismus daargestel het. Daarom dat hy dadelik na die vermelding van die Skepping oorgaan tot die onderhouding en bewaring en die vrug wat daaruit spruit, naamlik dat ons Hom moet loof en dank, dien en gehoorsaam. Calvyn se kategismus is breër van opset, en daarom kom vrae oor "die almagtige" en die betekenis van "hemel en aarde" ook voor. Ook hier loop die belydenis van die Skepper uit op sy onderhouding en regering van alle skepsels, wat "baie meer uitnemend is as toe Hy hulle geskape het" (vr. 27; Calvyn, 1981:9). Die hele belydenis van God as Skepper word omraam deur die groot gedagte van sy vaderlike sorg. Die eerste vraag was immers: "Waarom noem jy Hom Vader?" Vraag 22 en die lang uiteensetting van die voorsienigheid loop uit op die belydenis dat $\mathbf{H y}$ die enige God is wat deur sy wysheid, goedertierenheid en lankmoedigheid die hele verloop van die natuur bestuur (kyk aanhaling hierbo). Bowendien loop die belydenis van die voorsienigheid uit op die troos of "voordeel" wat hierdie kennis vir ons inhou 
(vr. 29). Net soos by Luther word die bewaring van God hier na vore gebring: ons kom tot rus en kalmte omdat ons weet dat die vyande deur God in toom gehou word, "aangesien dit God behaag het om vir ons Bewaker en vir ons saligheid 'n Beskermer te wees" (Calvyn, 1981:10).

Die Heidelberger lê, wat omvang betref, tussen Luther se Klein Kategismus en Calvyn se Geneefse Kategismus. Die skepping van alle dinge "uit niks" word beklemtoon, maar dan word, nes by Luther, dadelik oorgegaan tot die onderhouding en regering van alle dinge deur sy raad en voorsienigheid. Dit alles word bely binne die verband van die vaderlike sorg van God oor my. Die hoofsin van antwoord 26 lui immers: "Dass der ewige Vater unsers Herrn Jesu Christi ... um seines Sohnes Christi willen mein Gott und mein Vater sei, auf welchen ich also vertraue, dass ich nicht zweifle, Er werde mich mit aller Nothdurft Leibes und der Seele versorgen ...." (HK, 1919:315). Hierop volg, nes by Calvyn, 'n aparte vraag oor die voorsienigheid (vr. 27) en vind Calvyn se omskrywing dat God alles "deur sy krag en sy hand onderhou" in die Heidelberger weerklank en loop ook uit op die belydenis: "... und alles nicht von ohngefähr, sondern von seiner văterlichen Hand uns zukomme" (HK: 316). Eweneens soos by Calvyn volg hier ' $n$ aparte vraag oor die nut van die kennis van die skepping en voorsienigheid (vr. 28), waarin die "loof en dank" van Luther weerklank vind ("in voorspoed dankbaar moet wees") en die gemeenskaplike "bewaring" van Luther en Calvyn pragtig bely word in terme van die wete dat niks ons van God se liefde kan skei nie, "dieweil alle Creaturen also in seiner Hand sind, dass sie sich ohne seinen Willen auch nicht regen noch bewegen können" (HK: 316).

Dit is sonder meer duidelik dat Luther, Calvyn en die Heidelberger by alle individuele verskil in formulering wesenlik dieselfde sê: die geloof in "God, die Vader, die almagtige, die Skepper van hemel en aarde" word nie in terme van 'n abstrakte skeppingsgeloof bely nie maar in terme van God se konkrete vaderlike sorg en bewaring van die gelowige (vgl. ook Stauffer, 1978:62).

Dit is juis hierdie gemeenskaplike reformatoriese geloofsbetrokkenheid wat in Perkins se kategismus opvallend afwesig is - tot in die aparte vraag oor die voorsienigheid! Hoewel daar in die "eerste beginsel" na die geloof gevra word: "... what dost thou believe concerning God?", bly die vraag - buite die verband van die Twaalf Artikels - en veral die antwoord in die beskoulike steek en hoor 'n mens nie die geloofstaal van Calvyn nie. Dit word nog duideliker in die exposition, waar die ou (filosofiese) vraag na die bestaan van God weer gevra word - 'n vraag wat in die vroeëre konfessies van die Reformasie hoegenaamd nie ter sake was nie. Geen wonder dat in antwoord op hierdie vreemde vraag die ou kosmologiese en morele Godsbewyse weer om die hoek 
loer nie.

* Hierdie teologiese klimaatsverandering kan ook aan die hand van die eerste vraag van die exposition aangetoon word. Die vraag is reeds hierbo aangehaal maar volg ter wille van die argument weer hier:

Q What is God?

Calvyn meen dat dit vanweë sy abstrak-beskoulike aard 'n irrelevante vraag is:

(icvolglik speel die mense wat hulle ten docl gestel het om by die vraag "Wat is God"? vas te steck, met koue bespiegelings, aangesien dit vir ons van baie groler belang is om te weet wat sy heredanighede is en wat by sy natuur pas ... Kortom: wat help dit ons om 'n God te ken met wie ons niks te doen het nie? (Inst. 1.2.2).

Calvyn se kritiek is teen die skolastici gerig. Dis genoeg om hier nog net een opmerking te maak: Perkins se eerste vraag klop met dié van Thomas in sy Summa theologiae: Quid sit Deus?

* Die verandering van die inhoud en funksie van kennis wat nou rasioneel, abstrak, beskoulik en nie-saligmakend word, en losgemaak word van oortuiging of vertroue (persuasion), in terme waarvan geloof uitsluitlik geformuleer word, reflekteer bloot die omvangryker skolastieke dichotomie van natuur en genade waarin die gereformeerde teologie na die Reformasie teruggegly het (vgl. Schulze, 1983:41).

\section{SIOT}

'n Mens het waardering vir Perkins se poging om die Calvinisme te populariseer en daardeur die reformasie van die kerk in Engeland verder aan te help. Dat toestande in die kerklike lewe onder koningin Elizabeth nog te veel te wense oorgelaat het, is allerweë bekend (Pill, 1973:203-205; Moorman, 1973:216-220; Shaw, 1981:43-47). Die inleiding van Perkins se kategismus, gerig aan die onkundiges, is 'n sprekende bewys van die halfslagtigheid wat die Reformasie in Engeland teen die einde van die 16 de eeu nog steeds aangekleef het. Trouens, hierdie halfslagtigheid was onvermydelik vanweë politieke motiewe en nasionale aspirasies wat die Reformasie in Engeland van die begin af gekniehalter het.

Maar waarom die veranderde teologiese klimaat waarin Perkins se poging tot verdere 
reformasie plaasgevind het? Hiervoor kan verskeie redes aangevoer word.

\subsection{Die individualistiese kasuïstiek}

'n Reformasie waarin die "senuwee" van die kerklike tug blykbaar permanent verlam was, moes voortgehelp word met 'n morele program van individualistiese kasuïstiek ${ }^{3}$ (vgl. Shaw, 1981:72-75). Hiermee was die sillogistiese redenering, waarteen Luther in sy Disputatio contra scolasticam theologiam so geweldig kon toorn, terug in die teologie - en dan veral in sy praktiese vorm (vgl. Schulze, 1983:41).

\subsection{Aristoteles as opvoedkundige rigtingwyser}

Die aanvanklike fel reaksie teen die Skolastiek kon moeilik volgehou word, omdat 'n geskikte infrastruktuur nie beskikbaar was en nog nie uitgebou was nie. Daarom het Melanchthon wat die skole moes reorganiseer, Aristoteles as opvoedkundige rigtingwyser maar weer by die agterdeur ingebring omdat daar geen alternatief was nie. Aan die begin van die $17 \mathrm{de}$ eeu was Aristoteles weer die onbetwisbare outoriteit aan die universiteite - ook in Cambridge, waar Perkins gestudeer en later gedoseer het. Bowendien moes die Prostestantse teologie in die tyd van konsolidasie teen die Roomse kontrareformasie eenvoudig nog werk met die wetenskaplike wapens wat gemeenskaplik voor hande was, naamlik dié wat uit die arsenaal van die skolastiek kom. Daar is gemeen dat dit voordelig was om die Roomse op hierdie wyse met hulle eie wapens te bestry (vgl. Beardslee, 1977:7 e.v.).

\subsection{Die aksent op die mens}

Die langsaam maar sekere deurwerking van die Renaissance in Engeland gedurende die laaste helfte van die 16 de en die $17 \mathrm{de}$ eeu, het die aandag al meer op die klassieke geleerdheid, maar daarmee saam ook op die mens geplaas. Die kennis, wat vir Calvyn geloofskennis was, waarin na die God van genade vol verwondering en

\footnotetext{
${ }^{3}$ Hierdic individualisme, wat ook in verskeie formulerings van Perkins se kategismus (bv. oor wat gelool is) voorkom, moet onderskei word van die taal in die cerste persoon enkelvoud wat so dikwels in die Klein Kategismus en die Heidelberger voorkom. Die ek en my is persoonlike geloofstaal maar het nog altyd die ander in die $\operatorname{og}$ (ngl. byvoorbeeld H.K. Sondag 7). Net so is die ons van Calvyn nic gelyk aan onderwyser plus leerling (ek en jy) nic maar aan ek en die ander. Dit het Pin (1978:167:168) in 'n teksanalisc van die GK duidelik aangetoon.
} 
dankbaarheid gekyk word, word gaandeweg 'n algemeen toeganklike rasionele kennis wat ek het, maar waarby my geloofsbeslissing as vertroue gevoeg moet word. So word die verlustiging in die objektiewe heil waarin ons mag deel, ingeruil vir 'n subjektiewe heilsindividualisme met sy rasionele en tog subjektiewe kasuïstiek. Hiermee saam gebeur nog iets: dit wat in die Reformasie 'n eenheid vorm (byvoorbeeld kennis en vertroue), word uiteengebreek. Daarmee was die pad oop vir eensydige aksentlegginge in die teologie na alle kante toe: rasionalisme, voluntarisme, eınosionalisme.

\subsection{Invloed van die Skolastiek}

Hoe sterk die suigkrag van die Skolastiek met sy rasionele onderskeidings in die 16de eeu nog steeds was, is 'n klompie jare gelede (1978) deur Fatio ten opsigte van 'n redelike braak veld aangetoon: die geskiedenis van die verskillende uitgawes van Calvyn se Institusie na sy dood. Wie die verskillende uitgawes van die Institusie in Europa in die indeks van die Calvini opera nagaan, is verstom oor die verskeidenheid daarvan en die hoeveelheid uitgawes wat verskyn het. Normaalweg sien ons dit as barometer van Calvyn se invloed. Maar dan pla die raaisel: hoe kon die protestantse Ordodoksie in skolastieke bane ontwikkel as Calvyn se invloed so sterk was? Fatio lig die sluier oor hierdie raaisel deur aan te toon dat baie van hierdie "kompendiums" van die Institusie ' $n$ aangepaste Calvyn opdis. Die proses begin reeds met Colladon se uitgawe, kry momentum in Bunny se Compendium (1576) gerig aan dio studente van Oxford, en is in volle fleur met Delaune (Launeus, Lawne) se publikasie van Institutionis christianae religionis .... epitome wat in 1583 by Vautrollier in Londen verskyn het. Hiervan het Engelse en Nederlandse uitgawes verskyn. Hierdie werk wemel van skemas en tabelle waarin die Institusie oorsigtelik saamgevat word. Calvyn is met hierdie dor, verstandelike skematiek onherkenbaar vermink. Maar dis die "Calvyn" wat gelees is (moontlik ook deur Perkins) en wat gedoseer is deur mense soos Olevianus, Piscator en Colenius (vgl. Fatio, 1978:173-199). S6 het die Protestantse skolastiek homself in ' $\mathrm{n}$ bose kringloop gevoed.

Moontlik moet bogenoemde vier "redes" vir die teologiese klimaatsverandering ná die Reformasie nie as "oorsake" daarvan gesien word nie. Miskien is dit eerder simptome as oorsake van die klimaatsverandering waarin Perkins ook geleef en gewerk het.

Hoe dit ook al sy, hierdie klimaatsverandering het die teologie op die pad van aksentleggings met gepaardgaande, "kerkstigtings" gelei - 'n pad waarvan die skade wat berokken is, eers in ons eeu met sy nuwe belangstelling in die Reformasie aan die lig kom. 


\section{BIBLIOGRAFIE}

BEARDSLEE, J.W, 1977. Reformed dogmatics. Michigan : Baker Book House.

BOHATEC, J. 1966. Dic cartcsianische Scholastik in der Philosophic und reformicrten Dogmatik des 17. Jahrhunderts. Hildesheim : Olms.

CALVYN, J. 1611. Recucil des Opuscules, c'est à dire Petils Traictés de M. Iean Calvin. 2e ed., Genève : Stoer.

CALVYN, J. 1864-1897. Calvini opera quac supersunt omnia. Baum, J.W., Cunitz, A., Reuss, E. reds Brunsvigac : Schwctschke ct filium. 58 dele plus Indeks. (Afgekort : OC.)

CALVYN, J. 1979. Commentaries on the epistles of Paul to the Galatians and Ephesians. Translated by W. Pringle. Grand Rapids, Mich. : Baker Bonk House. (Calvin's commentaries, vol. 21.)

CALVYN, J. 1981. Calvyn se kategismus. In Afrikaans vertaal deur H.W. Simpson. Potchefstroom Potchefstroomse Teologiese Publikasies. (Afgekort: GK.)

CALVYN, J. 1984 Institusic van die Christelike godsdiens (1559). Vertaal deur H.W. Simpson. Potchefstroom : Calvyn Julilcum Boekefonds.

CHALKER, W.H. 1961 Calvin and some seventeenth century English calvinists. Ann Arbor, Mich. University microfilms. 312p. (Dissertation (Ph. D.) - Duke University.)

FATIO, O. 1978. Présence de Calvin à l'epoque de l'orthodoxic reforméc. Les abrégés de Calvin à la fin du 16e au 17e sièclc. (In Neuser, W.H., red. Calvinus ecclesiac doctor. Kampen : Kok. p.171 207.)

GK (Geneefse Kategismus)

kyk

CALVYN, J. 1981. Calyyn se kategismus. In Afrikaans vertaal deur H.W. Simpson. Potchefstroom: Potchefstroomse Tcologiese Publikasies.

HK

kyk

HEIDELBERGSE KATEGISMUS. 1919. Catcehismus oder christlicher Underricht, wie der in Kirchen und Schulen der Churfurstlichen Pfalts getrieben wird.(In Schaff, P., red. The creeds of

INST.

Christendom, vol. 3. New York: Harper \& Brothers. p.307.355.) (Algekort: HK)

kyk

CALVYN, J. 1984. Institusie van dic Christelike godsdiens (1559). Vertaal deur H.W. Simpson Potchefstroom : Calvyn Jubilcum Bockefonds

LUTHER, M. 1919. Dr. Martin Luthers Enchiridion: Der kleine Catechismus. (In Schaff, P., red. The creeds of Christendom, vol. 3. New York: Harper \& Brothers. p. 74-92.)

LUTHER, M. 1971. Luther: sol, ratio, erudio, Aristoteles. Probeartikel zum Sachregister der Weimarcr Lutherausgabe. Herausg. H.A. Oberman. Bonn : Bouvier.

MOORMAN, J.R.H. 1973. A history of the church in England. 3rd ed. London : Adam \& Charles Black. OC

kyk

CALVYN, J. 1864-1897. Calvini opera quae supersunt omnia. Baum, J.W., Cunith, A., Reuss, E. reds Brunsvigae : Schwetschke et filium.

PARKER, T.H.L. 1975. John Calvin: a biography. London : J.M. Dent \& Sons.

PERKINS, W. 1970. The works of William Perkins. Breward, I. red. Appleford: The Sutton Courteney Press.

PILL, D.H. 1973. The English Reformation 1529-58. London : University of London Press. 
PIN, J.P. 1978. Pour unc analyse textuelle du carcchisme (1542) de Jean Calvin. (In Neuser, W.H., red. Calvinus ecclesiae doctor. Kampen : Kok. p.159-170.)

REUTER, K. 1940. Wilhelm Amesius, der führende Theologe des erwachenden reformierte Pietismus. Neukirchen: Buchhandlung des Erzichungsvereins.

SCHUlzE, L.F. 1971. Calvin's reply to Pighius. Potchefstroom : Pro Rege. (Thesis (Doct. és Sc.Rel.) University of Strasbourg.)

SCHULZE, L.F. 1983. Die afbuiging van Calvyn se denke in die 17de eeu. Koers: 48(1):30-44.

SCHULZE, L.F. s.j. Die Heidelhergse Kategismus. Ongepubliseerde klasdiktaat.

SHAW, M.R. 1981. The marrow of practical divinity: a study in the theology of William Perkins. Ann Arbor, Mich: University microfilms international. 327p. (Dissertation (Th.D.) - Westminster Theological Scminary.)

STAUFFER, R. 1978. Quelques aspects insolites de la thěologie du premier article dans la prédication de Calvin. (In Neuser, W.H., red. Calvinus ecclesiae doctor. Kampen: Kok. p.47-68.)

TORRANCE, J.B. 1982. Calvin and Puritanism in England and Scotland - some basic concepts in the development of "Federal Theology". (In Van der Walt, B.J., red. Calvinus reformator. Potchefstroom : Potchefstroom University for Christian Higher Education. p.264-286).

WENDEL, F. 1963. Calvin: the origins and development of his religous thought. Translated by P. Mairet. London : Collins. 
